\title{
Des techniques en quête d'artistes, ou les complexes articulations entre l'art et la science
}

\section{Claude Chestier}

\section{(2) OpenEdition \\ 12 Journals}

Édition électronique

URL : https://journals.openedition.org/tc/726

DOI : $10.4000 /$ tc. 726

ISSN : 1952-420X

Éditeur

Éditions de l'EHESS

\section{Édition imprimée}

Date de publication : 1 novembre 1991

ISSN : 0248-6016

\section{Référence électronique}

Claude Chestier, "Des techniques en quête d'artistes, ou les complexes articulations entre l'art et la science », Techniques \& Culture [En ligne], 16 | 1991, mis en ligne le 10 janvier 2006, consulté le 29 septembre 2022. URL : http://journals.openedition.org/tc/726 ; DOI : https://doi.org/10.4000/tc.726

Ce document a été généré automatiquement le 29 septembre 2022.

Tous droits réservés 


\title{
Des techniques en quête d'artistes,
} ou les complexes articulations entre l'art et la science

\author{
Claude Chestier
}

